\title{
THE DILEMMA FACING LANDLORDS AND TENANTS: ENFORCING TENANCY TRIBUNAL ORDERS WHILE UPHOLDING PRIVACY INTERESTS
}

\author{
Helena Harbrow*
}

Private landlords are the major contributors of housing in the New Zealand rental market. For years landlords have complained of an inability to enforce Tenancy Tribunal orders obtained against tenants for their failure to pay rent pursuant to the Residential Tenancies Act 1986. Following complaints, the Ombudsman controversially recommended that tenants' address information held by government departments, in particular the Ministry of Social Development, be released to the Courts to facilitate the enforcement process. However, this solution fails to adequately address the source of the problem and further encumbers the success of the landlord tenant relationship.

Without effective enforcement options landlords may revert to their own methods to safeguard their investments. This has lead to the formation of bad tenant registers on the internet and the plea for landlords to be able to access, among other things, tenants' credit history as quasi credit providers under the Credit Information Privacy Code. During this process tenants' privacy rights are being diminished, and their ability to access proper housing potentially compromised. Strategies that reduce the risk for landlords, by letting them know which tenants are likely to pay their rent from the outset, and by facilitating the retrieval of outstanding payments, will nurture the landlord tenant relationship.

\section{INTRODUCTION}

Private landlords have become important players in national housing policy. Their position was enhanced by their successful application to the Ombudsman for review of the ineffective enforcement of Tenancy Tribunal Orders. For years private landlords have been unable to enforce judgment orders against tenants, simply because they could not provide the Courts with tenants'

\footnotetext{
* Submitted as part of the LLB(Hons) programme at Victoria University of Wellington.
} 
physical addresses to facilitate the enforcement process. Frustrated with government departments refusing to release this vital address information, private landlords took their case to the Ombudsman who controversially ruled in their favour in October 2002, four years after the initial request. The decision endeavours to assist private landlords by allowing address information to be made available to the Courts, serving the public interests of maintaining the proper administration of justice and promoting respect for the law.

Nevertheless, the ruling was made in conflict with the views of the Privacy Commissioner's office, the Ministry of Social Development (MSD) and tenant advocacy groups, who were concerned with the privacy interests that may be disregarded by the ruling.

In reality, both tenants and landlords violate the rights and responsibilities prescribed by the Residential Tenancies Act 1986 (RTA). However, the single largest cause of rental disputes that require assistance is tenants' failure to pay rent. ${ }^{1}$ Currently over $\$ 22$ million is outstanding in rent arrears. $^{2}$ As a result, there is a strong need to provide effective remedies to mitigate the loss experienced by private landlords, while at the same time improving processes, support and education to help tenants meet their rent payments.

The Ombudsman's 2002 ruling is contentious for several reasons. As a major contributor to society's housing, private landlords are able to exert influence over developments in national housing and government related policy. Comprehending the debate evolving between private landlords and tenants in the rental sector requires, an understanding of the current housing situation, the underlying role that landlords play, and the societal and political changes that have given private landlords prominence. The potential scope of the Ombudsman's decision must also be considered in light of the limited enforcement success claimed by private landlords, as they revert to their own methods to safeguard their property investment. This paper examines the controversial decision of the Ombudsman, first by considering whether competing privacy and public interests were appropriately weighed, and second by exploring the potential impact the ruling on the tenancy relationship in New Zealand.

\section{OVERVIEW OF DEVELOPMENTS IN THE RESIDENTIAL RENTAL SECTOR IN NEW ZEALAND}

The intervention by the Ombudsman into the landlord-tenant relationship in 2002 emerged from the lack of appropriate legislative measures to remedy abuse by tenants. This abuse was primarily in the form of tenants defaulting on rent payments, a key responsibility outlined in the RTA. ${ }^{3}$

1 Ministry of Housing Statement of Intent 2004 (Wellington, 2004) 14-15.

2 Geoff Boxall, President, Wellington Property Investors Association Inc "It keeps getting better" (May 2004) The Capital Property Investor Wellington 1 (editorial).

3 Residential Tenancies Act 1986, s 40(1)(a). 
Private landlords who had obtained Tenancy Tribunal Orders to recover monies owed were often placed in the anomalous position of being unable to lawfully enforce the orders. The technical difficulty of not knowing the current address of the tenant rendered the process futile. In order to comprehend how and why this may have occurred, and the potential impact this conflict imposes on society, an analysis of the key parties involved and the related societal developments must first be undertaken.

\section{A Who is Involved in the Tenancy Relationship and Related Disputes?}

A common misconception is that all private residential rental landlords (private landlords or, broadly, landlords) are affluent commercial players and, as such, are able to absorb financial loss when a tenant breaches their tenancy agreement. In reality, a large proportion of private landlords are of a non-commercial nature and are typically parents who invest in another property for family reasons or retirement income; first time home buyers who cannot afford the mortgage on their own income; or individuals who find they have a second home by default, through inheritance or for employment reasons. ${ }^{4}$ Statistically, private trusts are also included under the heading of private landlords. ${ }^{5}$ However, this latter form of property ownership often involves those trying to protect their assets in light of relationship property provisions applicable to de facto and married couples, and therefore does not necessarily lead to the same issues under review in this paper. ${ }^{6}$

Due to their diverse nature and composition explained above, private landlords can sometimes follow ad-hoc property practices, and are often reliant on their own commercial expertise and gut instinct to manage their properties. Many may be unfamiliar with the finer points of tenancy law and property investment, which leads to a significant proportion of private landlords joining groups, such as the Property Investors Association Inc or New Zealand Property Investors Federation Inc for further assistance and support. These organisations aim to assist, inform and educate their members in the relevant law governing the tenancy relationship and to advance better property investment practice. $^{7}$ Through education it is hoped that members will become more compliant with tenancy legislation, and failures in the tenancy relationship will be minimised. Additionally, these bodies advocate for landlord rights, keep abreast of relevant housing legislative developments and lobby

4 Ministry of Housing Building the Future: Towards a New Zealand Housing Strategy: Discussion Document (Wellington, 2004) 43.

5 Statistics New Zealand Renting Households: Sector of Landlord $<$ http://www.stats.govt.nz $>$ (last accessed 5 October 2005).

6 Property (Relationships) Amendment Act 2001, s 27; and Trustee Act 1956, Part 3.

7 Achieved through guest speakers at monthly membership meetings, seminars, workshops, panel discussions, telephone advice from Executive Committee Members and information provided in member publications including: The Capital Property Investor Wellington; The New Zealand Property Magazine Rotorua; and the Kiwi Property Investor Wellington. 
for landlord-friendly amendments. ${ }^{8}$ Few landlords use the services of property managers or real estate agents, expressing the opinion that such practice can impinge on financial gains and are unnecessary. ${ }^{9}$ This is in contrast to overseas jurisdictions, where the private rental market predominantly engages the professional services of property managers or real estate agents. ${ }^{10}$

As well as private landlords, there are public landlords that include Housing New Zealand Corporation (HNZC) under the instruction of the Department of Building and Housing. HNZC provides the majority of social housing and promotes the private residential rental market. ${ }^{11}$ Local government also comes under the public landlord umbrella, contributing to the provision of rental properties. ${ }^{12}$ Over the past decade the involvement of the public landlord in the rental sector has weakened significantly in comparison to the private landlord. ${ }^{13}$ This can be attributed to government and social policy changes, including the reallocation of crucial housing funding. ${ }^{14}$ In contrast to private landlords, public landlords, as part of the Executive, may be able to access extensive and reliable sources of tenants' personal information. This is because HNZC has the ability to access information (including tenants' new addresses), contained in bond lodgement applications which are maintained by the department. ${ }^{15}$ There is also the possibility that information held by other government departments may be accessible if an appropriate information matching policy and agreement were in place. ${ }^{16}$ Public landlords are therefore less likely to be involved in disputes that involve the recovery of debts owed, as they have more means to locate a tenant than a private landlord.

The decline of the public landlord in the rental sector has resulted in an increased presence of private landlords as suppliers of rental housing for the public. There is a virtual absence of private

8 See for example, Wellington Property Investors Association Inc "Submission to the Office of the Privacy Commissioner on the Proposed Credit Information Privacy Code 2003".

9 Wellington Property Investors Association Inc "Monthly Meeting" (The Royal Society Building, Thorndon, 26 July 2004).

10 Department of Housing, Queensland "Strategy Policy Directions" < http://www.housing.qld.gov.au> (last accessed 5 October 2005).

11 Ministry of Housing Statement of Intent 2004, above n 1, 14.

12 Ministry of Housing Statement of Intent 2004, above n 1, 14.

13 Statistics New Zealand "Sector of Landlord and Total Household Income, for Households in Rental Private Occupied Dwellings, 1991, 1996 and 2001" <http://www.stats.govt.nz> (last accessed 5 October 2005).

14 Hon Steve Maharey, Minister of Housing "Promoting Stable Tenancies" (27 May 2004) Press Release.

15 Ministry of Housing Report of the Ministry of Housing for the year ended 30 June 2003 (B.12, Wellington, 2003) 6 .

16 Privacy Act 1993, Part 10. 
landlords who invest in rental property solely for commercial purposes. ${ }^{17}$ The more accurate proposition appears to be that private landlords rely on regular income generated by rental properties for themselves and their family's livelihood. Therefore, if tenants default it is imperative that private landlords have appropriate recourse to recover these debts.

\section{Tenant Composition}

Residential tenants (tenants) are also a diverse group of individuals that include beneficiaries, professionals, extended families and students. ${ }^{18}$ Tenants also encompass migrants and persons suffering from mental illness or intellectual disability, requiring special protections due to their vulnerabilities. ${ }^{19}$ Potentially, boarders and those residing in boarding type facilities will also be included as tenants invoking the same protections, as predicted by the amendment to the RTA. ${ }^{20}$ An individual's status will change over time (for example, from university student to full time employee); so too will their housing status and their level of involvement in the rental sector. Arguably, every New Zealander will live in rental accommodation during some phase of their life for reasons of financial necessity or deliberate choice. ${ }^{21}$ As private landlords and tenants involve a significant portion of society, any conflict between them can impact greatly on society as a whole. For example, a tenant's right to adequate housing may be jeopardised, as could a landlord's right to maintain their property investment. Therefore, it is in society's best interests to provide appropriate resolution where disputes between these parties arise.

\section{B Societal Developments in National Housing Aiding Private Landlords}

Significant changes in society have impacted heavily on the condition of housing in New Zealand and subsequently improved the position of the private landlord as a key supplier of national housing. Demographically, society is continually changing as the two-parent nuclear family gives way to the more diverse household, featuring extended families and multiple cultures. $^{22}$ Changes in lifestyle preference and employment needs, plus factors including the impact of student loans, delayed family formation and lower finance rates, all continue to affect living

17 Ministry of Housing Building the Future: Towards a New Zealand Housing Strategy: Discussion Document, above n 4, 43. 29 per cent of private landlords are considered corporate investors, by reason of owning three or more properties.

18 Ministry of Housing Statement of Intent 2004, above n 1, 13.

19 Residential Tenancies Amendment Bill 2001, no 188-2 (the commentary) 2.

20 This is attributable to the rising interest rates, house prices and stable salary figures, evidenced in the 2001 Census statistics found at: Statistics New Zealand "Renting Households: Household Income" $<$ http://www.stats.govt.nz $>$ (last accessed 5 October 2005).

21 Ministry of Housing Building the Future: Towards a New Zealand Housing Strategy: Discussion Document, above n 4,42 .

22 Ministry of Housing Statement of Intent 2004, above n 1, 11-12. 
arrangements and future demand for housing. ${ }^{23}$ In addition, the real estate market has experienced significant growth, resulting in house prices sky-rocketing. ${ }^{24}$ Consequently, home ownership is financially beyond the reach of many individuals, resulting in longer periods of participation in the rental market. This is mainly due to substantial financial hurdles to entry into home ownership, as house prices surpass government valuation. ${ }^{25}$

Accordingly, the current housing position denotes growth in private property investment. While the number of homes privately owned has experienced a marginal improvement of two per cent from 1991 to 2001, rental properties have soared by 37 per cent nationally. Of the total number of rental properties, 74 per cent are attributed to private landlords, while only 22 per cent of the rental market remains in the hands of public landlords. ${ }^{26}$ Of interest is the reliance placed on private landlords, evidenced by the acquisition of 4,439 houses by HNZC since 1999, 36 per cent of these leased from private landlords. ${ }^{27}$ HNZC receives approximately 5,000 applications each month requesting state housing. ${ }^{28}$ Only around 300 applications are provided for by HNZC; the remainder are sourced from private landlords. ${ }^{29}$

While property prices have increased over the past decade, tenants and landlords have experienced only incremental rises in market rent. By implication, renting remains an affordable and viable housing option for the public. But the profitability of rental property investment is a cause for concern where the yields fall too far behind house prices. The likelihood of relying on capital gains and tax rebates to make a return on the rental investment may be short-lived as the government has decided to investigate the necessity of a capital gains tax for private property investments. ${ }^{30}$ The Ministry of Housing recognised these developments and introduced initiatives

23 Ministry of Housing Building the Future: Towards a New Zealand Housing Strategy: Discussion Document, above n 4, 8-9.

24 Ministry of Housing "Rent Statistics; Sales Statistics" (July 2004) The New Zealand Property Magazine Rotorua 48.

25 Dr Muriel Newman MP "Trouble Looming for Private Property Investors" (July 2004) The New Zealand Property Magazine Rotorua 38 ["Trouble Looming for Private Property Investors"].

26 This includes Housing New Zealand Corporation, local authorities and other government-owned housing. Statistics New Zealand "Renting Households: Sector of Landlord" < http://www.stats.govt.nz> (last accessed 5 October 2005).

27 Dr Muriel Newman MP "Guilty Until Proven Innocent: Update on RTA Changes" (May 2004) The New Zealand Property Magazine Rotorua 43 ["Guilty Until Proven Innocent"].

28 "Guilty Until Proven Innocent", above n 27, 45.

29 This figure is not set to improve with the additional resources allocated in the 2004 Budget. See "Trouble Looming for Private Property Investors", above n 25.

30 Parliamentary Office of the Clerk Financial Review of Treasury and the Financial Statements of the Government of New Zealand for the year ended 30 June 2003: Report of the Finance and Expenditure Committee (Wellington, 2003). 
particular to the rental sector through its Statement of Intent 2004 and Housing Strategy. ${ }^{31}$ The majority of these actions focus on enhancing the relationship between landlords and tenants to encourage further participation in the rental market. Initially this will be achieved by promoting stable, good quality housing and attempting to balance the conflicting needs of the parties in the tenancy relationship. ${ }^{32}$ Ultimately these considerations result in social benefits, including better health, education and employment outcomes. ${ }^{33}$

\section{The Role of the Private Landlord in Society}

From this discussion of societal changes and government responses, the essential role that private landlords play as significant suppliers of national housing begins to emerge. Private landlords provide two thirds of rental accommodation, amounting to a quarter of total housing. ${ }^{34}$ They are relied upon by the government to satisfy state housing needs and are referred to extensively in housing policy. ${ }^{35}$ Contented private landlords are considered crucial in ensuring the long-term feasibility of secure, quality housing. Inability to obtain reparation through the Tenancy Tribunal increases the financial risk of property investment and impedes participation. This may have a significant impact on the sustainability of the rental sector and, in turn, lead to detrimental effects on the economy and moreover tenants, whose ability to access adequate housing may be undermined as rent inflates. Additional financial pressure may be placed on the government to relieve tensions in the rental sector, no doubt at the expense of the taxpayer.

These factors indicate that there is significant public interest in resolving this dilemma and settling the difficulties experienced in debt retrieval by private landlords. Arguably, these tensions played an underlying role in influencing the Ombudsman's recommendation when considering the competing public interest in the release of tenants' personal information under section 9(1) of the Official Information Act 1982 (OIA).

\section{THE RESIDENTIAL TENANCIES ACT 1986 AND TENANCY DISPUTES}

Ultimately the landlord-tenant relationship is governed by the RTA. This Act sets out the regulatory framework for the rental housing sector, defining the rights and obligations of the parties

31 Note that the Ministry of Housing became the Department of Building and Housing in November 2004. Hon Steve Maharey, Minister of Housing "Building the Future: Towards a New Zealand Housing Strategy" (29 April 2004) Press Release. See generally: Ministry of Housing Building the Future: Towards a New Zealand Housing Strategy: Discussion Document, above n 4; and Ministry of Housing Statement of Intent 2004, above $\mathrm{n} 1$.

32 Hon Steve Maharey, Minister of Housing "Promoting Stable Tenancies" (27 May 2004) Press Release.

33 Ministry of Housing Building the Future: Towards a New Zealand Housing Strategy: Discussion Document, above n 4, 13.

34 Statistics New Zealand "Census Snapshot 12 (Housing)" (Wellington, 2002).

35 Ministry of Housing Statement of Intent 2004, above n 1, 2. 
and establishing a dispute resolution service, including a tribunal. The Tenancy Tribunal under the jurisdiction of the RTA is the only means by which tenancy related disputes are determined. ${ }^{36}$ It is a consumer-driven piece of legislation as all New Zealanders are recognised as being involved in housing as consumers. ${ }^{37}$ However, both landlords and tenants have expressed their frustration when exercising their rights under the RTA. ${ }^{38}$ The most significant problem with the RTA is faced by private landlords when seeking to enforce lawfully obtained Tenancy Tribunal judgments in their favour to recover the loss of financial benefits caused by tenant abuse of the relationship.

Private landlords initiate the majority of complaints received by tenancy services. ${ }^{39}$ This is reflected by the fact that the single largest cause of rental disputes requiring assistance with resolution is tenants' failure to pay rent. ${ }^{40}$ However, the reality is not necessarily represented by these statistics. Tenant Advocacy groups complain that few tenants bring applications to the Tenancy Tribunal as they cannot afford the application fee of $\$ 20$ and often feel incompetent to conduct their case against the landlord. They also claim that other causes of breakdowns in the tenancy relationship can be attributed solely to the landlord. These include the landlord's failure to do maintenance and their disregard of a tenant's right to quiet enjoyment of the premises, as evidenced by statistics generated by HNZC. ${ }^{41}$

Additionally, private landlords generally feel aggrieved by the different notice periods and procedures applicable to tenants under the RTA. ${ }^{42}$ There is also the perception that the Tenancy Tribunal favours tenants in its decisions, following the presumption that private landlords can afford to stand the loss. Nonetheless private landlords maintain that they endure the larger financial impairment in the tenancy relationship and as such should have at least equal, if not stronger, protections under the RTA, although having to relocate can be a heavy burden on a tenant's family.

36 Residential Tenancies Act 1986, s 77.

37 Ministry of Housing Statement of Intent 2004, above n 1, 10

38 See Karl du Fresne "More teeth sought for landlord-friendly law" (29 August 2003) The National Business Review Auckland; Hank Schouten "Privacy concerns over tenancy ruling plan" The Dominion Post Wellington.

39 Ministry of Housing Statement of Intent 2004, above n 1, 15.

40 Social Services Committee 2002/03 Financial review of the Ministry of Housing and the Housing New Zealand Corporation: Report of the Social Services Committee (Wellington, 2003).

41 Ministry of Housing Statement of Intent 2004, above n 1, 15.

42 Residential Tenancies Act 1986, s 51 . 


\section{HAS AN APPROPRIATE BALANCE BEEN STRUCK BETWEEN \\ COMPETING PUBLIC AND PRIVACY INTERESTS BY THE 2002 OMBUDSMAN RECOMMENDATION?}

\section{A Background to the Complaint}

From 1998 the Ombudsman received several complaints from individuals concerned that the debt enforcement process of civil orders was ineffective. ${ }^{43}$ The majority of claimants were private landlords aggrieved by their inability to enforce an obtained Tenancy Tribunal order against tenants who owed them debts. This was due to the landlord's failure to obtain tenants' current physical addresses to enable the Collections Unit of the Department of Courts to serve the order. As the tenant was often a beneficiary, private landlords tried to access address information held in government department databases (for example Work and Income New Zealand (WINZ), now under the operation of the MSD, by official information requests under the OIA. ${ }^{44}$ These requests were refused by the MSD (in agreement with the Privacy Commissioner) as the tenant's address information was considered a matter of privacy that needed to be protected under section 9(2)(a) and was additionally subject to an obligation of confidence under section $9(2)$ (ba) of the OIA. ${ }^{45}$ Moreover, there was no information matching agreement to facilitate the sharing of information between WINZ and the Department of Courts. ${ }^{46}$

The Ombudsman accepted the request to investigate the complaints. He then embarked on an arguably contentious journey leading to his decision in 2002 to disclose tenants' address information held by government departments in order to facilitate the enforcement of Tenancy Tribunal orders. This release was qualified by the condition that the address information be released directly to the Department of Courts, for the enforcement of Tribunal orders only. ${ }^{47}$ This decision was in conflict with the opinion of the Privacy Commissioner and the MSD, who believed that the release of such personal information breached an individual's right to privacy, was inconsistent with Information Privacy Principles (IPPs) and had broad implications on the civil judgment enforcement process. ${ }^{48}$ Further, tenant advocates were concerned that the decision could impose a form of discriminatory treatment towards tenants, who were effectively singled out from other civil debtors and also by the

43 Office of the Ombudsmen Report of the Ombudsman for the year ended 30 June 2003: Requests for address information held by Ministry of Social Development to assist enforcement of judgment orders privacy outweighed by countervailing public interest considerations (Wellington, 2003) 19.

44 Office of the Ombudsmen, above n 43, 19.

45 Office of the Ombudsmen, above n 43, 19.

46 Office of the Ombudsmen, above n 43, 18.

47 Office of the Ombudsmen, above n 43, 18.

48 Privacy Act 1993, s 6, Information Privacy Principle 11. 
fact that no reciprocal condition was made in favour of tenants to assist their retrieval of orders lodged against landlords. ${ }^{49}$

However, in light of these considerations, section 7 of the Privacy Act 1993 ultimately supported the proposition that the decision-making authority rest with the Ombudsman, within the jurisdiction of the OIA. Section 7 of the Privacy Act is a savings provision and affirms that the Act is subject to the provisions of any subsequent enactment which deals with a matter that would otherwise be determined by reference to the IPP's. ${ }^{50}$ In effect, the provisions contained in the OIA can override privacy interests and principles contained in the Privacy Act. Even though the OIA overrules the Privacy Act, there is still an obligation on the Ombudsman to consult with the Privacy Commissioner on matters of privacy. ${ }^{51}$

Due to their disagreement with the Ombudsman decision, Crown Law under direction of the MSD and the Privacy Commissioner initiated proceedings in the High Court, essentially seeking judicial review. ${ }^{52}$ The Property Investors' Federation (representative of private landlords) was also joined as third respondent to the proceeding. ${ }^{53}$ The main dispute involved the interpretation and weighting of the public interest envisaged in section 9(1) of the OIA which affirms that under certain circumstances: ${ }^{54}$

... good reason for withholding official information exists, ... unless, in the circumstances of the particular case, the withholding of that information is outweighed by other considerations which render it desirable, in the public interest, to make that information available.

The issue revolved around whether to construe section 9(1) interests narrowly, by the impact on the State, as there was no limitation to the public interest value determined by the Ombudsman. ${ }^{55}$ However, only days before the hearing, the proceedings were aborted by Crown Law presumably on clarification of the procedure of conditional release only to the Department of Courts. ${ }^{56}$

49 Human Rights Act 1993, s 65.

50 Paul Roth Privacy Law and Practice (looseleaf, Butterworths, Wellington) para 1007.2.

51 Official Information Act 1982, s 29B.

52 See Office of the Ombudsmen, above n 43, 19; where Crown Law initiated proceedings on the basis of a declaratory judgment but essentially sought judicial review of the hearings.

53 Office of the Ombudsmen, above n 43, 18.

54 Official Information Act 1982, s 9(1). See also: Office of the Ombudsmen New Practice Guidelines Official Information (Wellington, September 2002) Part B3.

55 Office of the Ombudsmen, above n 43, 19.

56 Office of the Ombudsmen, above n 43, 19. See also Question for oral answer: Landlords - Problem Tenants (19 June 2003) 609 NZPD 6429-6431. 
Whether the Ombudsman's decision to disclose personal information is appropriate in light of the strong countervailing public interests requires further scrutiny. Further, the motivations behind the decision to uphold the administration of justice is also problematic considering the limited value the provision of an address affords. Why private landlords are the only recipients of such favourable treatment is also open to discussion.

\section{B Is the Release of Address Information in Breach of the Privacy Act 1993 and the Official Information Act 1982?}

The first consideration must entail whether a government department is entitled to withhold address information once a request is made for its release under the OIA. Clearly a person's address retained by a government department fulfils the definitional criteria of official information, ${ }^{57}$ and personal information, ${ }^{58}$ as it is information held by a department that identifies an individual.

A further question must then be asked: whether the information may be withheld to protect privacy interests. This is conducted by an assessment under section 9(2)(a), which provides that there is good reason for withholding information if, and only if, the withholding of the information is necessary to protect the privacy of the person. ${ }^{59}$ Further, the privacy interest to withhold information must not be outweighed by the public interest in making the particular information available as envisaged in section 9(1) of the OIA. These competing public and private interests to withhold or release information must be identified and assessed to ascertain which is the superior right. Factors influencing the strength of the privacy interest include the lack of consent given by the individual and any inconsistency with IPPs, in particular IPP 11, which provides guidance for when disclosure should occur. Essentially, IPP 11 covers the instances when personal information is permitted to be disclosed. The difficulty arises in this case because the release of an individual's personal information by the MSD is in contradiction to the purposes for which it was gathered and retained. ${ }^{60}$ Furthermore, individuals may have been compelled to provide this information to the State in order to obtain much needed welfare benefits, indicating that the information may not have been sourced from the public arena. ${ }^{61}$ However, there is a contrary view applicable in these circumstances permitting disclosure by the exceptions prescribed in IPP 11(e)(i) and (ii); in the interests of avoiding prejudice to the maintenance of the law by a public sector agency, or for the enforcement of a law imposing a pecuniary penalty. It is unlikely though that Tenancy Tribunal orders were intended to be captured by these parts, as the nature of the orders primarily aim to

57 Official Information Act 1982, s 2.

58 Official Information Act 1982, s 2; Privacy Act 1993, s 2.

60 Privacy Act 1993, s 6, Information Privacy Principle 11(a).

61 Privacy Act 1993, s 6, Information Privacy Principle 11(b). 
recover outstanding debts or monies owed and only in rare cases impose additional or significant pecuniary penalties. ${ }^{62}$ This implies that there are significant privacy interests to be considered before the release of an individual's address information can proceed under section 9(2)(a) of the OIA.

However, while privacy interests are important, they are not absolute, as illustrated earlier by the operation of section 7 of the Privacy Act, enabling the provisions contained in the OIA to take precedence. Privacy interests are confined and even negated by the pressing public interest in making the information available under section $9(1)$ of the OIA. ${ }^{63}$ The release of an address was considered to aid the enforcement process by enabling Tenancy Tribunal orders to be served to the debtor, maintaining the proper administration of justice and upholding respect for the law. ${ }^{64}$ The private landlord who has adhered to the legal rules that govern society, and in particular the tenancy relationship, should be rewarded by being able to serve the order and obtain financial relief, following principles of natural justice. This position is also supported by the underlying principle that official information should be made available, as captured by section 5 of the OIA and affirmed in the decision of Commissioner of Police $v$ Ombudsman. ${ }^{65}$ This decision involved the judicial review of the Ombudsman's ruling which considered the Police refusal to disclose personal information concerning the requesting individual involved in a dispute with the Police. The Ombudsman found that the Police refusal to disclose the information was unjustified and the information should be made available. ${ }^{66}$ The leading proposition from the case states that when the decision-maker is in two minds at the end of their assessment between the privacy interest to withhold and the countervailing public interest to make information available, the information should be made available. ${ }^{67}$ In this case the strong public interest in preserving confidence in the maintenance of the law and enabling the enforcement of justice to occur were significant countervailing public interests ultimately favouring disclosure.

The other enquiry concerning the refusal to disclose current addresses under section 9(2)(ba) invited a two-step review by the Ombudsman. ${ }^{68}$ First, a determination of whether the information was subject to an obligation of confidence or compulsion by statutory authority is required. As address information is required in order to obtain State social welfare benefits, this fulfils the first

62 Residential Tenancies Act 1986, ss 78 and 107.

63 Office of the Ombudsmen New Practice Guidelines - Official Information, above n 54, Part B5.

Office of the Ombudsmen, above n 43, 19.

Commissioner of Police v Ombudsman [1988] 1 NZLR 385 (CA).

Commissioner of Police v Ombudsman, above n 65, 411, para 25 (CA) Casey J.

7 Commissioner of Police v Ombudsman, above n 65, 391, para 45 (CA) Cooke P. 
inquiry. The second inquiry concerned whether its release would cause harm to the individual or prejudice the further supply of similar information. ${ }^{69}$ Arguably, the release of information for ulterior purposes by a government department demonstrates misuse of State power over its citizens, supporting the contention that information should be withheld under section 9(2)(ba). Further, as the MSD primarily holds beneficiaries' personal information, disclosure could inadvertently lead to discriminatory treatment of a class of individuals, bringing the department in conflict with the Human Rights Act $1993 .^{70}$ An individual's current address has a significant privacy interest. However, the perceived harm by its release is limited, favouring the contention that the information should not be withheld. Further support for disclosure is provided by the principle of natural justice, where a tenant in default should not be protected from being held accountable for their actions.

\section{The Scope of the Ombudsman's 2002 Decision}

Because the contractual association of landlord and tenant connotes a creditor and debtor type relationship, the Ombudsman's decision can potentially impact negatively on general credit relationships. As it stands, there is no limitation to the possible interpretation of the Ombudsman decision, nor to the type of people who may access personal information held by a government department. Potentially all civil judgment orders involving the recovery of outstanding debts can be caught by the Ombudsman decision, as they also involve an aggrieved creditor who faces a dilemma like that of private landlords. However, the decision is arguably narrowed by the investigatory process undertaken by the Ombudsman, choosing tenancy related complaints only and only consulting parties concerned with the release of personal information for the strict purpose of enforcement of Tenancy Tribunal orders. ${ }^{71}$ As the Ombudsman decision requires each case to be considered on its merits, its scope was restricted to those subject to the investigation and review only, excluding other general civil judgment orders. ${ }^{72}$ As this would result in the anomalous treatment of aiding the enforcement of current Tenancy Tribunal order requests and not those initiated prior to the decision, a second recommendation was made so the MSD could also consider previously refused requests for the supply of current address information. ${ }^{73}$ While the extent of its

69 Office of the Ombudsmen New Practice Guidelines - Official Information, above n 54, Part B4.3.

70 Human Rights Act 1993, s 65.

71 Including the Ministry of Housing, Ministry of Social Development, Department of Courts, Tenancy Tribunal Adjudicator and Privacy Commissioner.

72 Office of the Ombudsmen, above n 43, 19.

73 Office of the Ombudsman, above n 43, 19. 
application in general disputes is far from clear, there also appears to be no restraint on the type of government department databases that may fall prey to its exploration. ${ }^{74}$

As a result of the recommendations, the information databases held by the MSD and the Department of Building and Housing can be accessed to retrieve tenants' current address information by interim initiatives instigated by HNZC. ${ }^{75}$ The ruling has extensive consequences if construed in a broader sense to include general governmental databases. Fears mount that any public sector database that falls under the microscope of the OIA jurisdiction may be vulnerable, if challenged, to release information to satisfy similar public interest values. This includes databases held by the Ministry of Health and the Police. As the search environment enlarges, the range of personal information being accessed may increase too and the risk of individuals' private information being disclosed unnecessarily or misused heightens.

\section{Was the Ombudsman the Appropriate Body to Determine the Dispute?}

Effectively, the Ombudsman's decision may have contributed towards legislative amendment favouring landlord-friendly changes to the RTA. The corresponding effect for tenants would be the degradation of their privacy rights. While the Ombudsman had a practical and legal duty to remedy this complaint, arguably the more appropriate path was legislative amendment incorporating sufficient consultation and input from the public. ${ }^{76}$ This may have additionally ironed out concerns over the scope of the ruling and whether it is applicable to creditors in general who may also be unable to enforce civil judgment orders to recover monies owed.

Prior to the Ombudsman's decision, ACT Party MP Dr Muriel Newman had drafted a Private Member's Bill known as the Social Securities (Facilitation of Deductions and Recoveries) Amendment Bill (the Bill), to address this major concern of recovery of outstanding debts. ${ }^{77}$ The Bill would enable the location details of defaulting tenants to be provided by the MSD to an agent of the court for collection purposes, and would allow beneficiaries to have their rent deducted at source to private landlords (mirroring the process already utilised for public landlords) to avoid falling behind on rent. The Bill also aimed to address the failures of the Residential Tenancies Amendment

74 Presently only the Ministry of Social Development, Work and Income, and the Department can access their databases to track down an address, as mentioned in the Ombudsman decision: Office of the Ombudsmen, above n 43, 19.

75 Department of Building and Housing "Supporting Stable Tenancies" < http://www.dbh.govt.nz $>$ (last accessed 10 October 2005).

76 Ombudsman Act 1975, s 13; Official Information Act 1982, s 28.

77 See Dr Muriel Newman MP "Housing the Nation" (Speech to Property Investors Association, Nelson, 18 April 2002); citing the Social Securities (Facilitation of Deductions and Recoveries) Amendment Bill proposed by the Member. 
Bill (RTA Bill), which were raised to a great extent in submissions. ${ }^{78}$ Instead, the RTA Bill focuses heavily on bringing boarding houses and boarders under the jurisdiction of tenancy law. ${ }^{79}$

While this 2002 Private Member's Bill never came to fruition, the key intentions were endorsed by the Ombudsman's decision and the subsequent initiatives adopted by the then Ministry of Housing later that year. The existence of the Private Member's Bill demonstrates that legislative redress was available and may have been a more appropriate forum to address the concerns and adopt measures in an open and frank environment. Further support for legislative process is shown by the significant length of time between the initial request in 1998 (although the problems were likely to have occurred since the inception of the RTA), and the declaration issued four years later, raising concerns over the complexities of the investigation and legal issues considered. ${ }^{80}$ Both aggrieved landlords and concerned Members of Parliament had brought the matter to the attention of the Minister of Housing for his review. ${ }^{81}$ Whether the Office of the Ombudsmen was the proper body to make a decision that inherently challenged the bearing and validity of civil procedure, arguably already under review, is debatable. ${ }^{82}$

Further, as the area of contention fell primarily under the general jurisdiction of the Ministries of Housing and Justice, these departments may have (with the agreement of other government departments who supply the information) ${ }^{83}$ imposed a form of resolution by amendment to the RTA or the civil disputes procedure under the District Court Act 1947 (authority for the Tenancy Tribunal). This would have provided more credibility and certainty, as it would clearly prescribe measures necessary for compliance. This is in contrast to the Ombudsman's decision, which provides no parameters on how a government department or agency must give effect to its recommendation. In turn, little accountability is provided for private landlords or tenants. Private landlords are unsure of how to proceed with applying for the information and there is no opportunity for right of review or appeal of a decision made by the agency upon their refusal to action a request.

The logic behind the Ombudsman's decision to ensure that enforcement can occur is arguably tenuous, as the mere provision of an address certainly does not guarantee that reparation, or even any payments, can be achieved. Of the applications received to access addresses, approximately

78 Residential Tenancies Amendment Bill 2001, no 188-2 (the commentary) 6.

79 Residential Tenancies Amendment Bill 2001, no 188-2 (the commentary) 4.

80 Office of the Ombudsmen, above n 43, 19

81 Office of the Ombudsman, above n 43, 19. See also: Office of the Clerk of Parliament "Questions Of The Day Transcript: 11. Landlords-Problem Tenants" (19 June 2003) Press Release.

82 District Courts Act 1947, Part 6; Summary Proceedings Act, ss 87AA and 87A (Part 3).

83 Such as the agreement of the MSD permitting their databases to be accessed to provide address information to the courts. 
two thirds have been successful. ${ }^{84}$ Little is known of the success rate in regards to firstly receiving the awarded compensation per the tribunal order, and secondly the timeliness of repayment.

\section{E The Interim Measures to Facilitate the Ombudsman's Decision}

The Ministry of Housing voluntarily employed interim initiatives to give effect to the Ombudsman's decision on a discretionary basis. ${ }^{85}$ In order for private landlords to obtain a tenant's address from the Ministry of Housing, they must prove that they possess a sealed Tenancy Tribunal order and have conducted their own tracing exercise to locate the debtor, providing some safeguards for tenants' privacy. ${ }^{86}$ When they have completed this, then they are more likely to be approved by the Ministry of Housing and a government database search will be initiated.

Constraints on the type of databases subject to the process can also create difficulties, when the debtor is not a beneficiary or fails to register another bond, leaving their personal information concealed from the Ministry of Housing's scrutiny. This raises doubts over the effectiveness of the Ombudsman's decision. The purpose of recommending government departments release the address information was in the public interests of upholding the law and the proper administration of justice. However, these ideals cannot be reconciled simply by suppyling a tenant's address. A more comprehensive civil enforcement procedure must be produced to give effect to such broad objectives intended by the Ombudsman. The Ombudsman's decision, while made with good intentions, has limited success in achieving its purpose, and is still proving onerous (requiring further alternative searches to have been undertaken) on the private landlord who has complied with the legal process and should receive justice. As this process is only an interim measure until encapsulated in future legislation, a clearer and more robust process is necessary to settle these inconsistencies.

\section{THE EMERGENCE OF ALTERNATIVE METHODS TO PROTECT AGAINST ADVERSE TENANTS?}

The so-called "victory" of the Ombudsman's ruling for landlords has been bitter-sweet. In fact, the practical solution that was praised by the Ombudsman is realised as only a step in the right direction for the attainment of justice; sufficient in the interim, but begging for a structured and comprehensive scheme to be implemented. To combat the potential liability and risk of the perceived ineffectiveness of tenancy legislation and the Ombudsman's ruling, the creation of internet-based "bad tenant" databases or broader tenancy databases has emerged. ${ }^{87}$ In addition,

84 Dr Muriel Newman "Landlord Developments" (May 2004) The New Zealand Property Magazine Rotorua 43.

85 See Department of Building and Housing "Request for release of address information" form, available at $<$ http://www.dbh.govt.nz> (last accessed 6 October 2005).

"Request for release of address information" form, above $\mathrm{n} 85$.

87 New Zealand has approximately 7 tenancy databases operating, accessible by database search. 
private landlords and associated groups have raised the plea to first allow them to continue conducting credit checks of prospective tenants with their consent and, further, to set up a national register of Tenancy Tribunal decisions online. These practices have arisen to enable private landlords to make an informed choice when selecting a prospective tenant, by being privy to further information to assess foremost their financial ability to meet rent payments.

\section{A The Operation of Internet-based Tenancy Databases}

These bad tenant and tenancy databases operate as a useful vetting mechanism for private landlords in their selection of prospective tenants. Essentially, they perform an important function for landlords by effectively alerting them to any risk, financial or otherwise, that may have been recorded by a tenant's previous landlord. ${ }^{88}$ As private landlords are the ultimate drivers of these databases, the information posted usually consists of both personal and public information concerning the adverse conduct or behaviour of a former tenant which may or may not have lead to a breach of the rights and responsibilities under the RTA. ${ }^{89}$ Finding a tenant listed on the site sends warning signals to future landlords to beware of the potential risk they may pose.

These databases can prove harmful for tenants who may be refused a rental property on the mere basis of their name being found on one of these sites, regardless of the purpose for which it is listed. Tenants may also never know that they are listed on one of these databases or that the listing was the reason they were denied a rental property, as there is no regulation governing this practice, in accordance with standard privacy principles under the Privacy Act.

Regardless, this practice of recording information about bad tenants is relatively new in New Zealand, but is growing in popularity. The concept of tenancy (or tenant-default) databases has been investigated and is undergoing significant development in the state of Queensland, Australia. ${ }^{90}$ It has also raised concerns in the United Kingdom in the landlordsdata.com case, where a major property manager set up his own database recording an extensive list of personal information of bad tenants on the site, raising suspicions by the public of his compliance with data protection laws. ${ }^{91}$ However, these jurisdictions differ from the practice in New Zealand, as private landlords primarily employ property managers to look after their properties, leading to distinct issues irrelevant to this discussion.

88 Some databases provide for good and bad information concerning landlords and tenants to be made available, but these additional categories are very rarely utilised. See $<$ http://www.personalreference.co.nz $>$ (last accessed 6 October 2005) which includes comments praising good tenants and landlords.

89 Residential Tenancies Act 1986, ss 36-49.

90 Report of the Special Government Backbench Committee To Inquire into the Operation of Tenancy Databases (Government of Queensland, 2002).

91 Peter Carey "The Strange Case of Landlordsdata.com" (2000) 1 PDP 11. 
In Queensland, tenancy databases are always used by property managers. They are not regulated by the State and have had devastating effects for tenants, in some cases resulting in homelessness. ${ }^{92}$ Privacy legislation is also weak; demanding little compliance from database operators. ${ }^{93}$ In the United Kingdom however, privacy protections are considerable by operation of the Data Protection Principles in the Data Protection Act 1998, which operates very similarly to New Zealand's Privacy Act 1993. Parallels can be drawn between these jurisdictions to assess the potential risks of established tenancy databases in New Zealand.

\section{B Tenancy Databases: the Impact on an Individual's Privacy}

Of concern is that these internet databases vary substantially by the subject matter, operating standards and security of information found on their website. The operation of these databases may breach an individual's right to privacy, as private landlords are not allowed to broadly list any personal information concerning a former tenant to third parties limited by the application of IPP 11 . For example, one website simply provided on a non-secure, easily accessible web page, a list of individuals' names and aliases that were being sought in relation to their being a "bad tenant, beware!". ${ }^{94}$ In general though, database sites require the user to log in and register first before a search can be undertaken, agreeing that they do so on the premise that they are accessing the site for lawful purposes and are a landlord. Landlords must also disclose their personal and credit card details before the search can commence. This initial procedure provides some security for monitoring the correct use of the information and maintaining the integrity of the site. Unfortunately, the registration process can be manipulated and avoided, meaning anyone can potentially access and list information on the site. ${ }^{95}$ These safeguards illustrate that database operators and landlords have given some consideration to protecting the information and restricting access to it, thus aligning themselves with privacy principles. Most identifiable database operators and landlords were concerned about the application of privacy legislation and their subsequent level of compliance, often having a dedicated privacy policy on their site. ${ }^{96}$ While information can be shared between landlord groups legitimately, difficulties arise concerning restricting access to that specified group, and regulating the content and accuracy of information on the tenancy database.

92 Fiona Guthrie Recommended Queensland Government Strategy Regarding Tenancy Databases prepared for the Residential Tenancies Authority (Creative Sparks Pty Ltd, Bardon (Qld), 2002) 35.

93 Report of the Special Government Backbench Committee To Inquire into the Operation of Tenancy Databases, above n 90, 7 .

94 This webpage is no longer available $<$ http://www.badtenant.rental.co.nz $>$ (last accessed 6 May 2004).

95 This is achieved by entering incorrect personal details resulting in being able to list and search information on the site potentially for no charge, as the database invoices a system on use.

96 See for example $<$ http://www.personalreference.co.nz $>$ (last accessed 6 October 2005) where an extensive part of the site is dedicated to privacy compliance. 
Often the information found on the database consisted of the tenant's personal details, including their name and aliases, age, occupation, cultural ethnicity, and distinguishing features (for example, tattoos). ${ }^{97}$ Tenancy Tribunal Orders, including whether compensation remained outstanding, were also commonly listed. Generally, information concerning political, social and sexual preferences and religion were excluded in accordance with the Human Rights Act 1993. ${ }^{98}$ However, some databases permitted information concerning a rating system determinable by the landlord, which included references to property damage and noise complaints. ${ }^{99}$ The difficulty illustrated by these examples is that often the type of information supplied is subjective to the landlord and can be incorrect or inaccurate. This is in conflict with IPP 8 of the Privacy Act, which provides that agencies must take reasonable steps to check the accuracy and relevance of information before it is used.

If there is no obvious criterion prescribing reasons for listing a person on a database, then the ability to challenge their inclusion and correct the information as provided by IPP 7 is extremely limited. An individual may never know they are listed on a database, nor is there any obligation on a prospective landlord who learns of this information to disclose it to the prospective tenant. This has occurred in Queensland, proving extremely detrimental to those tenants who were unable to access adequate housing for years and sometimes were left homeless. They were not informed that they were on a tenancy database, and had they given their consent for information about them to be listed in the first place. ${ }^{100}$ In New Zealand however, the privacy principles under IPP 6 apply and individuals are entitled to access information that may be held on any of these tenancy databases by request. The common practice is for private landlords who provide information to databases to accept the responsibility to maintain and verify its authenticity in line with IPP 2 . This is acquired by the tenants' express consent, having them sign a waiver included in the standard rental agreement that their information may be used for other purposes, usually lawful. The tenant should be informed that their personal information may be disclosed to a tenancy database and which one, in accordance with IPP 3. ${ }^{101}$ In the United Kingdom, consent is also required before the information may be listed on the site, in compliance with the First Data Protection Principle. ${ }^{102}$ Should consent not be given, either the information will not be listed, or the database holder will be obliged to contact the person directly to request their consent. This places a more onerous obligation on the database holder than the practice followed in New Zealand. If private landlords are able to exercise

97 See <http://www.personalreference.co.nz $>$ (last accessed 6 October 2005) which contains photographs of individuals to aid recognition.

98 Human Rights Act 1993, s 53.

99 See $<$ http://www.tenantcheck.co.nz $>$ (last accessed 6 October 2005).

100 Guthrie, above n 92, 16.

101 Privacy Act 1993, s 6, Information Privacy Principle 3.

102 Data Protection Act 1998 (UK), s 4, First Data Principle. 
unfettered power over the disclosure of tenants' information, this may create substantial barriers for tenants seeking to obtain further housing.

Most tenancy databases also require copies or references of the Tenancy Tribunal Order to ensure that the information is in the public domain and is lawful, complying with privacy principles. Some databases do attempt to inform the individual that a search has been conducted, but this contact is usually for the ulterior motive of gauging their whereabouts for debt collection, another service some databases provide. ${ }^{103}$

If landlords simply forget to remove the listing, a tenant's details can remain on the site forever, as there is no policing function to keep the information current or accurate, adding another obstacle to tenants' ability to access housing.

The main impact these databases may have on a tenant's right to privacy is that they may operate to prejudice an individual's right to housing in New Zealand, by essentially blacklisting them for no lawful reason. Currently, only IPP 11 of the Privacy Act provides some limitations to private landlords creating their own database of what they consider to be problem tenants and distributing these to other landlords who may also contribute their version of bad tenants and so on. There is little accountability for landlords, but high risk for tenants. As New Zealand has around seven different databases that are run independently, the likelihood of internet databases becoming a major threat to an individual's right to housing at this stage is limited. However, with the growth of the rental market and the increased use of property managers, internet databases will be likely to be accessed more regularly. A major deterrent for private landlords at present is the cost and time to have to run several searches to learn whether a potential tenant is listed. If the expense of utilising searches could be tax deductible and the databases amalgamate into two or three large operations, then the difficulties experienced in Queensland may surface and require attention. The likelihood of this occurring is high, as indicated already by the amalgamation of two tenancy database operators who now boast that they list over 70 names each week. ${ }^{104}$

\section{National Register of Tenancy Tribunal Orders}

A national register of Tenancy Tribunal Orders may remove the need for tenancy databases. The register could serve a similar function to tenancy databases, but more reliably and on a national scale. If the register was maintained by the Department of Building and Housing, the information provided would be lawful, accurate and timely, and removed after a period of time. Information of both landlords and tenants who have had tenancy tribunal orders enforced against them would be

103 See < http://www.personalreference.co.nz> (last accessed 6 October 2005) additional services including employee credit checks and other forms of debt retrieval are offered.

104 See for example the amalgamation of tenancy database <http://www.tenanttinz.co.nz> into $<$ http://www.cia.co.nz $>$ (last accessed 6 October 2005). CIA boasts that they had more than 22,000 names listed on the site, at the end of March 2005. 
included, promoting fairness, aiding transparency and ultimately fostering a more cohesive tenancy relationship for the future. ${ }^{105}$ This register would also alleviate individual privacy concerns, as the difficulties over the subject matter able to be listed would not arise.

\section{Landlords' Fears about the Credit Information Privacy Code}

A recent initiative from the Privacy Commissioner's Office raises further concern from private landlords and landlord associations. This appears in the form of the proposed Credit Information Privacy Code 2003 (Code) (proceeding through the consultation process), which regulates an individual's credit information and imposes restrictions and constraints over access to it. The Code consists of an extensive list of credit information privacy rules and the exceptions that apply.

Under the proposed Code, landlords would not be considered to supply credit services and therefore would not fall within the definition of credit providers to be able to access credit information concerning prospective tenants. A credit provider is defined to be "an agency that carries on a business of reporting on the creditworthiness of individuals", while credit is defined as "property or services acquired before payment, and money on loan". ${ }^{106}$ As tenants generally pay their rent in advance, tenancy situations will not be covered within the narrow definition of credit until payments are in arrears, which for practical purposes is too late for landlords. ${ }^{107}$ This means that landlords will be unable to vet a prospective tenant's previous credit history before the tenancy commences. Once they have breached the tenancy agreement, discovering they have a bad credit history is of little value. The Code in its present form will be of no assistance to landlords.

As stated in the consultation paper on the Code, ${ }^{108}$ only some landlords will come within the definition of credit provider. This will be dependant on their rent payment method. Such an artificial distinction has stirred landlords to call for tenancy situations to be added to the definition of credit and for landlords be included as credit providers. ${ }^{109}$ Any of these additions would contradict the ordinary meaning of credit to include a specific criteria advanced by an influential and significant group. ${ }^{110}$ It would also seem likely that such an inclusion would be beyond the scope of

105 See Hon Steve Maharey, Minister of Housing "Promoting Stable Tenancies" (27 May 2004) Press Release; referring to the Budget 2004 initiatives, including investigating a national register of tenancy orders.

106 Proposed Credit Information Privacy Code 2003, cl 4.

107 New Zealand Property Investors Federation Inc "Submission to the Office of the Privacy Commissioner on the Proposed Credit Information Privacy Code 2003".

108 Office of the Privacy Commissioner Consultation on Proposed Credit Information Privacy Code: Information Paper (Wellington, 2003).

109 Ministry of Housing "Submission to the Office of the Privacy Commissioner on the Proposed Credit Information Privacy Code 2003".

110 See generally Wellington Property Investors Association "Submission to the Office of the Privacy Commissioner on the Proposed Credit Information Privacy Code 2003". 
the Code, which aims at regulating credit information to ensure lending decisions can still be made and relied on. This would be achieved by imposing minimum standards to restrict the period of time information can be withheld, and the amount and type of information able to be accessed and by whom. This effectively establishes accountability and improves transparency of operations for credit providers and credit agencies while maintaining a level of privacy protection for individuals' sensitive credit information. ${ }^{111}$

It can be argued that, like the credit checks of prospective clients that are used by credit providers under the Code, landlords too should be able to access the credit history of prospective tenants. Renting differs only slightly from entering into a credit relationship or hire purchase agreement. Hire purchase credit providers can in theory retrieve the goods in satisfaction for the debt, and the failure to make payments would attract an adverse credit record, perhaps preventing subsequent applications for credit. However, in rental arrangements there are many ways that tenants can abuse the tenancy relationship that can amount to a substantial and often unrecoverable loss for the landlord. If a tenant fails to make rent payments the private landlord only has recourse to a tenant's bond, which is often insufficient due to the time incurred before an application may be made and the fact that property damage may occur which will not be satisfied by the bond. Due to the time factor and high financial risk that landlords face in this quasi credit-like relationship with tenants, being able to reduce the likelihood of pecuniary harm by exercising a credit check is essential.

Despite the fact that landlords may not fit within the traditional view of creditors, their relationship with tenants is akin to a creditor-debtor relationship, especially when rent is in arrears. This supports their inclusion as a special class within the Code. However, including landlords under the guise of "credit provider" potentially opens the door for other groups who use, and rely on credit information for a particular purpose to be included too (for example, contractors and employers). This consequence is simply unworkable. It casts the net too wide, potentially allowing a significant proportion of groups to be captured as credit providers. This fails to adhere to the purpose of the Code which aims to create a regulatory framework with minimum credit standards restricting access to an individual's credit information. ${ }^{12}$ Moreover, if landlords were included, the criteria to determine any limitations would be a complex and intricate matter in an attempt to distinguish their inclusion from other similar groups in the Code. Perhaps the size of the group would assist their argument for access to the information, as landlords are a significant proportion of society providing fundamental housing resource to New Zealanders. These reasons suggest that it would be unrealistic and impractical for landlords to bring themselves within the boundaries of the Code.

111 Office of the Privacy Commissioner, above n 108, 2.

112 Proposed Credit Information Privacy Code 2003, s 5, Part 2. 
The Code potentially imposes further obstacles for landlords, preventing their access to prospective tenants' credit information even with express permission. This may assist some tenants who have an adverse credit rating, but for the majority of rent-paying individuals the imposition of further restrictions on private landlords raises concerns of alternative methods for placating their fears.

\section{RECOMMENDATIONS FOR REFORM}

The Ombudsman's decision in 2002 has produced only fragmented resolutions for private landlords trying to enforce Tenancy Tribunal orders. In order to improve the tenancy relationship in general and give effect to Tenancy Tribunal orders, a more comprehensive approach must be assumed.

First, greater recognition needs to be given to the source of the problem leading to the majority of disputes, which is the inability of tenants to pay rent and the inadequate provision of residential rental housing provided by the State. While the latter is outside the scope of this article, it can be noted that the former was challenged by the introduction of new procedures by the Department of Building and Housing in co-operation with the MSD. These consist of enabling beneficiary tenants (the instigators leading to the Ombudsman's ruling) to have their rent payment (or rent arrears) paid directly to the rental provider. This practice cuts out the middle-man, removing the temptation and opportunity for tenants to use rent money for alternative purposes. ${ }^{113}$ However, this practice is in its early stages and is optional for beneficiaries. While this may create stigma towards beneficiaries by treating them differently to employees, for example, this is necessary in the State's and their own interests to support their living arrangements. In reality, private landlords know when a tenant is a beneficiary, and using a process that guarantees their rent payments would simply improve their appeal during the selection process.

Other strategies employed by the Department of Building and Housing have similar objectives. One such strategy is a nationwide educational programme of seminars for landlords focusing on practical ways to manage rental properties, tenant relationships and business risk. ${ }^{114}$ Similar programmes could be made available to educate and inform tenants of their rights and responsibilities when entering into a tenancy agreement. Further, these programmes could be provided as part of a "preparation or orientation package" for high school leavers, tertiary students and community groups attempting to instil good practice and ethics for those likely to enter the rental market. While this raises issues of resources and funding, the $\$ 22$ million currently

113 Social Services Committee, above n 40.

114 Department of Building and Housing "Supporting Stable Tenancies" < http://www.dbh.govt.nz/> (last accessed 6 October 2005). 
outstanding in rent arrears gives some indication of the importance of addressing tenants' failure to pay. ${ }^{115}$

Further investment by the government into the rental sector must also be encouraged, as proposed by the Budget 2004. ${ }^{116}$ This would have the effect of rebalancing the housing market, enabling government to fulfil its social responsibilities to provide appropriate housing options for those in need. Moreover, it could lower market rents and improve the affordability and quality of rental properties.

A significant overhaul of the RTA and related provisions in the District Courts Act 1947 and its civil procedure must be instigated by the Department of Building and Housing and the Ministry of Justice respectively. The then Minister of Housing, Steve Maharey, announced that a significant allocation of the Budget 2004 funds would be used to provide a comprehensive review of the RTA, an Act over 20 years old. ${ }^{117}$ The District Courts Act however is over 50 years old and must certainly be ripe for review. Further providing for the waiving of the application fee for tenants to bring a claim to the Tenancy Tribunal and additionally evening the notice periods to a flat 90 day period for both landlord and tenant would also enhance the equality of treatment the parties receive under the RTA, aiding confidence in the legal process.

The controversial Ombudsman's decision resulted in only a partial remedy for private landlords in abeyance of privacy interests. While the Ombudsman arguably made a fair assessment of the competing privacy and public values in disclosing address information held by particular government databases, the essence of the decision needs to be further incorporated in legislation. The Department of Building and Housing and the MSD actioned interim measures but these need to be fleshed out and provided equally for both parties who obtain Tenancy Tribunal orders which, for lack of address information, are unable to be enforced. By incorporation into legislation, deficiencies, including the prejudicial treatment favouring the private landlord, will be settled. As stated, private landlords also cause some of the breakdowns of the tenancy relationship thereby supporting the proposition that tenants should also have access to disclosed address information. Further, where the line is drawn between Tenancy Tribunal orders and civil judgments is murky and must be made clear by legislation. This would uphold the law and prevent ambiguity which currently leads to constant challenges to the Ombudsman or government departments to gain access to particular information for recovery of debts in general.

The evolution of "bad tenant" databases and professional property services also requires additional safeguards to be imposed to prevent the situation in Queensland from occurring. The

115 Boxall, above n 2, 1 .

116 Department of Building and Housing "Supporting Stable Tenancies" < http://www.dbh.govt.nz/> (last accessed 6 October 2005).

117 Report of the Social Services Committee 2004/05 Estimates Vote Housing (Wellington, 2004). 
various treatment and compliance levels of internet tenant databases suggests a pressing need for minimum standards to be set. This could be achieved by introducing regulatory framework under an extended jurisdiction of the RTA administered by the Department of Building and Housing. A code of conduct would need to be formed and clearly provide minimum operating standards in cohesion with privacy principles, including legal recourse under the Tenancy Tribunal for disputes over the content of information posted. Currently the privacy principles are confining the use of some information being made available on these sites, but arguably a more specialised approach must be determined. This is especially so in light of the significant repercussions highlighted in Queensland.

Standard rental agreement forms would also need to be restructured and further education would need to be implemented for both landlords and tenants, ensuring that before consent is given the terms of reference are clear, understandable and restricted to housing matters within the law. Signing a form that allows information to be used for "lawful purposes in general" is too vague and should be revised in accordance with the Privacy Act 1993 to ensure that the tenant is aware of the potential use, purpose and potential future recipients of the information. There must be some control over the creation and subject matter of these databases, as their mere existence can have a debilitating effect on an individual's participation in the rental housing market.

Alternatively, the creation of a free (or inexpensive), nationwide and user-friendly online Tenancy Tribunal Register which records all Tenancy Tribunal orders for both private landlords and tenants, would alleviate much of the demand created by tenancy databases. The Register would be accessible by both parties in a tenancy relationship, but only to check a potential tenant or landlord. Permission may also be required by the individual to search their name, in order to restrict usage to proper purposes only. The new register, coupled with the amendment and revision of the RTA and DCA to reflect current societal values would undoubtedly promote good faith dealing and public confidence in the administration of justice, which has arguably been devalued.

\section{CONCLUSION}

Undoubtedly, tenants already face unfairness, prejudice and discrimination in the selection process for rental housing, be it for the car they drive, or lack thereof, or to the number of visible piercing they have. ${ }^{118}$ The likely impact of removing a private landlord's right to access credit information, even when given express permission, raises concerns of whether they will try to seek some underhand method to obtain a prospective tenant's credit history or merely increase rent and bond amounts to cover the perceived risk to their property investment. Either way, it is an undesirable position for a tenant. However, landlords are not credit providers in the traditional sense and including them in the proposed Credit Information Privacy Code, will lead to other groups

118 "How to pick a tenant?" (June 2004) Property Investors Association Magazine Wellington 4. 
who provide quasi-credit functions to question why they too are not provided for, leading to a floodgates effect. As stated by a major recognised credit provider in New Zealand:

Integrity is paramount with credit information and personal information. It must be robust and reliable and above reproach. 